\title{
Deskripsi Sikap Siswa Terhadap Pelajaran IPA Berdasarkan Adopsi Sikap Siswa, Kesenangan Belajar IPA, dan Ketertarikan Belajar IPA di SMPN 16 Kota Jambi
}

\author{
Afniati Anas ${ }^{1}$, Riko Firmansyah ${ }^{2}$ \\ ${ }^{1}$ SMP N 16 Kota Jambi, Jambi, Indonesia \\ ${ }^{2}$ Pendidikan Fisika, Universitas Jambi, Jambi, Indonesia
}

\begin{tabular}{l} 
Article Info \\
\hline Article history: \\
Received Jun 29, 2020 \\
Revised Agu 4, 2020 \\
Accepted Sep 7, 2020 \\
\hline
\end{tabular}

Keywords:

IPA

Sikap

Siswa SMP

\begin{abstract}
ABSTRAK
Tujuan Penelitian: Penelitian ini bertujuan untuk mendeskripsikan sikap siswa terhadap Pelajaran IPA berdasarkan indikator adopsi sikap ilmiah siswa, kesenangan dalam belajar IPA, dan ketertarikan berkarir dalam bidang IPA di SMP Negeri 16 Kota Jambi. Siswa di SMP tersebut agar bisa diperbaiki dalam proses belajar demi meningkatkan semangat dalam diri siswa menjadi lebih baik jika terdapat hambatan-hambatan dalam pelaksanaannya.
\end{abstract}

Metodologi: Melalui desain penelitian, dapat diberikan gambaran mengenai apa tujuan, mengapa dilakukan penelitian serta bagaimana masalah dalam penelitian tersebut diteliti dengan menggunakan prinsip-prinsip metodologis. Pada penelitian ini kami menggunakan angket untuk memperoleh data dari sampel penelitian.

Temuan utama: Hasil analisis dan deskripsi sikap siswa terhadap pelajaran IPA berdasarkan indikator - indikator yang digunakan dapat disimpulkan bahwa belum semuanya siswa tidak memahami secara keseluruhan dari sikap IPA ini, bagaimana cara mengaplikasikannya dan lain sebagainaya. Dengan begitu, guru disini sangat berperan penting agar sikap siswa dapat berubah sesuai harapan.

Keterbaruan penelitian: Penelitian ini merupakan penelitian yang memiliki keterbaruan pada populasi yang diteliti dan pada Indikator penelitian yang digunakan. Penelitian terhadap sikap siswa dalam pembelajaran IPA di SMP 16 Kota Jambi berdasarkan indikator Adopsi Sikap Siswa, Kesenangan, dan Ketertarikan Belajar IPA

This is an open access article under the $\mathrm{CC} B Y-N C$ license

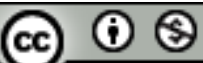

Corresponding Author:

Riko Firmansyah

Program Studi Pendidikan Fisika, Universitas Jambi,

Email: riko,firman@gmail.com

\section{PENDAHULUAN}

Dalam kehidupan, manusia tidak bisa lepas dari pendidikan. Melalui pendidikan, manusia dapat menggali potensi yang ada dalam diri mereka. Pendidikan merupakan wadah yang dapat membentuk sikap dan karakter anak bangsa. Pendidikan merupakan usaha sadar dan terencana sebagai suatu proses transfer ilmu, nilai, dan pembentukan kepribadian dan bertanggung jawab dalam melahirkan warga negara Indonesia yang memiliki karakter kuat yang sebagai modal dalam membangun peradaban tinggi dan unggul, [1-3]. 
Pendidikan dapat juga dikatakan sebagai kunci dari keberhasilan para peserta didik dikarenakan dengan adanya pendidikan, para peserta didik bisa lebih melek dengan dunia luar pendidikan dapat dijadikan sebagai alat perubahan sosial dan investasi dalam pembangunan nasional [4-7]. Pembangunan Indonesia akan sejalan dengan pembangunan pendidikan diIndonesia karena pada dasarnya Pendidikan merupakan ujung tombak dalam pengembangan sumber daya serta merubah tingkah laku dan pengetahuan baik di lingkungan keluarga maupun masyarakat [8-13]. Oleh karena itu, pendidikan merupakan hal penting untuk dapat mengembangkan pendidikan secara terus-menerus sesuai dengan perkembangan zaman.

Namun jika berbica tentang perkembangan maka Indonesia masih jauh dari kata maju. Hal ini dibuktikan dari rendahnya skor prestasi Indonesia masih berada di bawah skor rata - rata general, Rendahnya kualitas belajar siswa diIndonesia juga dapat diketahui dari indikator kualitas proses dan hasil belajar. Yang mana hal ini diakibatkan oleh kurang aktifnya dalam mengikuti pembelajaran yang diberikan oleh guru [1416]. Maka untuk menyelesaikan permasalahan tersebut pemerintah melakukan berapa perombakan , salah satunya melalui kurikulum, dan terbententuklah kurikulum 2013 yang berbasis teknologi, karena tidak dipungkiri pada zaman serba modern ini banyak pelajaran yang dituntut untuk tersedianya media pembelajaran digital menjadi sumber belajar bagi siswa [17-19]. Selanjutnya jika berbicara tentang pendidikan tentunya sangat berkaitan dengan proses pembelajaran.

Proses belajar menjadi penting karena, tercapainya suatu pendidikan yang baik tergantung pada bagaimana proses pembelajaran di suatu sekolah tersebut berlangsung. pada umumnya, proses belajar mengajar adalah kegiatan interaksi antara guru sebagai pengajar dan peserta didik sebagai pelajar. Melalui interaksi ini, maka diharapkan guru dapat mengarahkan siswa agar berperilaku dan memiliki sikap dan karakter yang baik. Pembelajaran merupakan usaha pendidik utuk mewujudkan terjadinya proses pemerolehan pengetahuan, penguasaan kemahiran, dan pembentukan sikap dan kepercayaan pada peserta didik [20-21]. Dalam proses pembelajaran, bukan hanya berkenaan dengan usaha guru untuk mentransfer pengetahuan pada peserta didik. Yang tidak kalah penting adalah bahwa dalam proses pembelajaran, terjadi suatu proses dimana lingkungan siswa secara disengaja dikelola untuk memungkinkan ia turut serta dalam tingkah laku tertentu dalam kondisi-kondisi khusus atau menghasilkan respons terhadap situasi tertentu. Hal ini tentunya sesuai dengan tujuan akhir dari proses pembelajaran yang memiliki tujuan akhir dari proses belajar mengajar adalah terjadinya perubahan tingkah laku anak [22]. Dalam proses pembelajaran di sekolah tentunya mengajarkan banyak materi pelajaran, salah satunya adalah mata pelajaran IPA.

Pembelajaran IPA merupakan pembelajaran yang ada di sekolah dari sampai tingkat lanjut. IPA atau sains merupakan ilmu pengetahuan yang mempelajari mengenai alam semesta dengan isi - isinya lengkap dengan peristiwa - peristiwa yang terjadi didalamnya yang sebelumnya telah dikembangkan oleh para ahli melalui proses yang panjang dan secara ilmiah dan dilakukan secaara teliti serta hati - hati yang pada saat SMP memiliki peran yang penting dalam membentuk siswa yang berkualitas[23-25]. Di dalam mata pelajaran IPA akan mempelajari ilmu fisika. Fisika merupakan bagian dari Ilmu Pengetahuan Alam yang menguraikan dan menganalisis struktur dari peristiwa-peristiwa di alam, teknik dan lingkungan berdasarkan hubungan sebab akibat yang pada akhirnya muncul kaidah-kaidah atau hukum-hukum dalam fisika [26]. Baik pelajaran IPA maupun fisika khususnya sangat erat kaitannya dengan kehidupan sehari-hari. Mata pelajaran IPA merupakan pembelajaran yang ruang lingkup cakupannya lebih kepada alam sekitar dan lingkungannya dan pada pelajaran IPA Terpadu terdapat kewajiban untuk membentuk karakter peserta didik melalui kegiatan pembelajaran (intra-kulikuler) [27-28]. Maka dari itu dalam pembelajaran IPA, diperlukan sebuah pemahaman yang mendalam tentang sikap siswa.

Sikap siswa terhadap pembelajaran IPA dianggap penting dikarenak pembelajaran IPA sering dianggap sebagai pembelajaran yang sulit dan penuh tantangan. Walaupun pembelajaran Ini dianggab sulit guru tetap diharuskan untuk melakukan penilaian afektif (sikap) disamping penilaian penilaian kognitif dan psikomotor [29]. Namun, Proses penilaian afektif (sikap) serta penilaian keterampilan proses disekolah belum dilakukan secara terperinci [30]. Sedangkan untuk kemampuan berpikir secara kritis, siswa di sekolah sudah mampu untuk melakukannya dengan baik [31]. Dalam perkembangannya terdapat beberapa komponen dasar yang menandakan bahwa siswa tersebut memiliki sikap ilmiah. Sikap siswa terhadap pembelajaran IPA dibagi kedalam beberapa indikator salah satunya adalah sikap ilmiah. Sikap ilmiah harus ditanamkan kepada seorang anak melalui pembelajaran di sekolah. Diketahui bahwa Proses pembelajaran merupakan kegiatan yang dirancang oleh pendidik dalam membantu siswa mempelajari suatu kemampuan atau nilai yang baru [32-32]. Sikap merupakan salah satu faktor yang mempengaruhi proses pembelajaran yang berasal dari dalam diri siswa serta dapat mempengaruhi keberhasilan dalam proses pembelajaran tersebut, dan proses pembelajaran selalu didukung oleh lingkungan yang baik [34-36]. Sehingga sikap siswa dalam pembelajaran IPA menjadi persoalan tersendiri bagi seorang guru yang sedang mengajar IPA disekolah.

Untuk mengukur bagaimana sikap siswa terhadap pelajaran IPA berdasarkan indikator adopsi sikap ilmiah siswa, kesenangan dalam belajar IPA, dan ketertarikan berkarir dalam bidang IPA di SMP Negeri 16 Kota Jambi peneliti melakukan penelitian menggunakan beberapa angket yang akan disebarkan di sekolah 
yang dituju. Penelitian ini memiliki keterbaruan dari indikator yang diteliti, dengan siswa yang terdiri dari kelas VII Dan kelas VIII. Penelitian ini bertujuan untuk mendeskripsikan sejauh mana sikap siswa terhadap pelajaran IPA berdasarkan indikator adopsi sikap ilmiah siswa, kesenangan dalam belajar IPA, dan ketertarikan berkarir dalam bidang IPA di SMP tersebut.

\section{METODE PENELITIAN}

Penelitian ini menggunakan metode penelitian mix method dengan desain eksplanatori. Desain eksplanatori adalah desain mixed methods yang dilakukan dalam dua tahap penelitian, yakni tahap kuantitatif, dan dilanjutkan dengan tahap kualitatif, dan diakhiri dengan menginterpretasikan hasil penelitian [37]. Dan pengambilan data dilakukan dengan metode survey. Metode survey, sendiri yaitu sebuah cara Pengumpulan informasi yang dilakukan dengan memberikan pertanyaan lisan maupun tulisan [38]. Peneliti menggunakan angket sebagai media survey.

Penelitian ini dilakukan di SMP 16 kota jambi dengaan jumlah populasi sebanyak 153 orang siswa yang terdiri dari dua angkatan yaitu angkatan kelas VII dan angkatan kelas VIII. Dan angket yang telah disebarkan dianalisis menggunakan metode penelitian deskriptif kuantitatif. Penelitian kuantitatif adalah penelitian empiris yang datanya berbentuk angka-angka [38]. Angket yang digunakan merupakan angket sikap yang diadaptasi dari Astalini dan Kurniawan (2019), dengan 56 butir pernyataan valid dan Cronbach Alpha sebesar 0,842 dimana angket tersebut dikatakan reliable atau layak untuk digunakan. angket ini menggunakan skala Likert dengan model lima pilihan (skala lima) yaitu : 1) Sangat Tidak Setuju (STS) ; 2) Tidak Setuju (TS); 3) Netral (N); 4) Setuju (S); 5) Sangat Setuju (SS).

Penelitian ini bertujuan untuk mendeskripsikan sejauh mana untuk mendeskripsikan sikap siswa terhadap pelajaran IPA berdasarkan indikator adopsi sikap ilmiah siswa, kesenangan dalam belajar IPA, dan ketertarikan berkarir dalam bidang IPA di SMP Negeri 16 Kota Jambi. Siswa di SMP tersebut agar bisa diperbaiki dalam proses belajar demi meningkatkan semangat dalam diri siswa menjadi lebih baik jika terdapat hambatan-hambatan dalam pelaksanaannya. Dengan dilakukannya penelitian ini, maka diharapkan dapat memperluas pengetahuan peneliti khususnya, serta membantu peneliti lain yang melakukan penelitian serupa sekaligus membantu guru dan semua pihak yang terlibat dalam dunia pendidikan untuk melakukan perbaikan dalam proses pembelajaran demi meningkatkan karakter peduli lingkungan dalam diri siswa menjadi lebih baik jika terdapat hambatan-hambatan dalam pelaksanaannya.

\section{HASIL DAN PEMBAHASAN}

Untuk meneliti tentang sikap siswa terhadap pelajaran IPA di SMP Negeri 16 Kota Jambi maka terdapat tiga Indikator yang digunakan dalam penelitian ini yang meliputi adopsi sikap ilmiah siswa, kesenangan dalam belajar IPA, dan ketertarikan berkarir di bidang IPA.

\subsection{Adopsi Sikap Ilmiah Siswa}

Data hasil penyebaran angket dari adopsi sikap ilmiah siswa akan di jabarkan dari data penyebaran angket tentang sikap siswa dengan indikator adopsi dari sikap ilmiah siswa yang disajikan dalam tabel 1.

Tabel 1. Hasil Adopsi dari sikap ilmiah siswa SMP 16 Kota Jambi

\begin{tabular}{|c|c|c|c|c|c|c|c|}
\hline \multicolumn{3}{|c|}{ Karakteritik } & \multirow{2}{*}{ Mean } & \multirow{2}{*}{ Median } & \multirow{2}{*}{ Min } & \multirow{2}{*}{ Maks } & \multirow{2}{*}{$\%$} \\
\hline Interval & Sikap & Total & & & & & \\
\hline $7,0-12,6$ & Sangat Tidak Baik & 1 & & & & & 0,7 \\
\hline $12,7-18,2$ & Tidak Baik & 17 & & & & & 11,1 \\
\hline $18,3-23,8$ & Cukup & 99 & 21.64 & 21.00 & 12 & 32 & 64,7 \\
\hline $23,9-29,4$ & Baik & 34 & & & & & 22,2 \\
\hline $29,5-35,0$ & Sangat Baik & 2 & & & & & 1,3 \\
\hline & Total & 153 & & & & & 100 \\
\hline
\end{tabular}

Bisa dilihat dari yang telah disajikan dalam tabel 1 diatas bahwa siswa yang telah mengadopsi sikap ilmiah di SMP Negeri 16 Kota Jambi adalah sebanyak 36 siswa atau sekitar 23,5\% saja, walaupun nilai ini lebih besar dari pada siswa belom mengadopsi sikap ilmiah yaitu sebesar 18 orang atau sebanyak 11,8\% siswa, sedangkan untuk siswa yang menjawab dengan jawaban cukup atau netral di angket yaiitu sebanyak 99 orang atau $64,7 \%$ siswa. Data diatas menjelaskan bahwa banyak dari siswa yang bingung dengan cara mengadopsi sikap Ilmiah itu sendiri. 
Adopsi sikap ilmiah sendiri merupakan suatu prose yang dimana seorang siswa dalam menerapkan sikap sikap ilmiah dalam kehidupannya. Adopsi dari sikap ilmiah adalah siswa yang menempatkan dirinya sebagai ilmuwan serta bersikap ilmiah dengan segala macam kehidupan dan kebiasaannya [39]. Siswa dapat mengadopsi atau melakukan sikap ilmiah dengan adanya sedikit dorongan, karena pada dasarnya pada diri seorang siswa telah ada sifat penasaran yang sangat besar. Adanya rasa ingin tau akan kebenaran memperlihatkan bahwa siswa memiliki sikap ilmiah yang baik. Dimana, Sikap tersebut mendorong siswa untuk penasaran, sehingga membuat siswa bertanya-tanya dan semangat siswa untuk menemukan jawaban permasalahan juga meningkat [40]. Sikap ilmiah sangat penting bagi siswa yang duduk dibangku SMP karena siswa dituntut untuk memahami konsep-konsep IPA dan siswa juga dibekali dengan kemampuan untuk melakukan percobaan-percobaan IPA untuk memicu pemahaman dan wawasan siswa dalam memahami pembelajaran IPA [41].

\subsection{Kesenangan dalam Belajar IPA}

Dari penyebaran angket di SMP Negeri 16 Kota Jambi didapatkan hasil penelitiannya yang akan dijabarkan pada tabel 2 .

Tabel 2. Kesenangan Belajar IPA SMPN 16 Kota Jambi

\begin{tabular}{|c|c|c|c|c|c|c|c|}
\hline \multicolumn{3}{|c|}{ Karakteritik } & \multirow{2}{*}{ Mean } & \multirow{2}{*}{ Median } & \multirow{2}{*}{ Min } & \multirow{2}{*}{ Maks } & \multirow{2}{*}{$\%$} \\
\hline Interval & Sikap & Total & & & & & \\
\hline $9,0-16,2$ & Sangat tidak baik & 2 & & & & & 1,3 \\
\hline $16,3-23,4$ & Tidak baik & 28 & & & & & 18.3 \\
\hline $23,5-30,6$ & Cukup & 89 & 27.00 & 26.00 & 19 & 42 & 58.2 \\
\hline $30,7-37,8$ & Baik & 34 & & & & & 22,2 \\
\hline $37,9-45,0$ & Sangat baik & 0 & & & & & 0 \\
\hline & Total & 153 & & & & & 100 \\
\hline
\end{tabular}

Dari tabel 2 diketahui bahwa sebanyak 34 orang siswa atau sabanyak 22,2\% siswa senang belajar IPA dan sebesar 19,6\% siswa atau sebanyak 30 orang siswa tidak senang belajar IPA sedangkan selebihnya berada pada angka 89 orang atau sebanyak 58,2\% siswa yang cukup senang atau netral dalam menyenangi pelajaran IPA.

Semua hal akan terasa lebih ringan jika dilandaskan dengan kesenangan atau kesukaan terhadap sesuatu, begitu juga dengan pembelajaran IPA akan lebih menarik jika siswa tersebut menyukai pelajaran IPA Kesenangan belajar dalam sains (IPA) dapat didefinisikan bahwa setiap siswa yang memiliki sikap positif terhadap sains harus memiliki kenyamanan dan merasakan kesenangan [34].Kesenangan dalam belajar IPA merupakan salah satu sikap positif siswa yang berarti rasa suka siswa saat sedang belajar IPA yang diikuti dengan rasa ingin tahu yang tinggi,Kesenangan belajar dalam IPA dapat didefinisikan bahwa setiap siswa yang memiliki sikap positif terhadap IPA harus memiliki kenyamanan dan merasakan kesenangan [43]. Faktor Kesenangan dalam belajar IPA dipengaruhi oleh faktor internal dan fator eksternal. Faktor internal atau dari dalam adalah perasaan yang timbul dari dalam diri siswa yang artinb ya siswa tersebut memang menyukai pelajaran IPA . Rasa senang dalam belajar IPA juga dipengaruhi oleh guru mata peljaran IPA itu sendiri ysng disebut fsktor eksternal.

\subsection{Ketertarikan Berkarir di Bidang IPA}

Hasil dari sebaran angket sikap siswa terhadap mata pelajaran IPA dalam indikator ketertarikan siswa berkarir dibidang IPA, dapat dilihat pada tabel 3.

Tabel 3. Hasil Ketertarikan Berkarir di Bidang IPA SMPN 16 Kota Jambi

\begin{tabular}{|c|c|c|c|c|c|c|c|}
\hline \multicolumn{3}{|c|}{ Karakteritik } & \multirow{2}{*}{ Mean } & \multirow{2}{*}{ Median } & \multirow{2}{*}{ Min } & \multirow{2}{*}{ Maks } & \multirow{2}{*}{$\%$} \\
\hline Interval & Sikap & Total & & & & & \\
\hline $9,0-16,2$ & Sangat tidak baik & 0 & & & & & 0 \\
\hline $16,3-23,4$ & Tidak baik & 31 & & & & & 20.3 \\
\hline $23,5-30,6$ & Cukup & 95 & 2,98 & 3.00 & 2 & 5 & 62.1 \\
\hline $30,7-37,8$ & Baik & 26 & & & & & 17.0 \\
\hline \multirow[t]{2}{*}{$37,9-45,0$} & Sangat baik & 1 & & & & & 0,7 \\
\hline & Total & 153 & & & & & 100 \\
\hline
\end{tabular}

Dari tabel 3 dapat diketahui bahwa terdapat sebanyak 27 orang atau terdapat 17,7\% siswa yang tertarik berkarir dibidang IPA, dan sebanyak 31 orang atau sebanyak 20,3\% siswa yang tidak tertarik belajar 
IPA sedangkan sebanyak 95 orang siswa atau sebanyak 62,1\% siswa ragu -ragu atau tidak tahu mau berkarir di bidang IPA atau tidak. Keragu - raguan ini muncul dikarenakan mereka masih ragu apakah mereka menyukai bidang ini atau tidak.

Kebanyakan siswa tidak tertarik untuk bekerja dibidang IPA dikarenan harus menenpuh pendidikan yang banyak dan akan sangat membosankan [42, 43], karena pada dasarnya siswa yang bisa memahami fungsi IPA dalam kehidupan sehari-hari, hanyalah peserta didik yang berprestasi baik di bidang IPA, berbakat dalam sains, dan sangat baik dalam matematika.

\section{KESIMPULAN}

Berdasarkan hasil analisis dan deskripsi sikap siswa terhadap pelajaran IPA berdasarkan indikator indikator yang digunakan dapat disimpulkan bahwa siswa belum semuanya siswa tidak memahami secara keseluruhan dari sikap IPA ini, bagaimana cara mengaplikasikannya dan lain sebagainaya. Ini bisa dilihat dari semua indikator mendapatkan kesimpulan yang sama yaitu banyak siswa yang menjawab dengan netral atau ragu - ragu, sehingga peran guru sangat dibutuhkan dalam hal ini.. Hasil yang tidak baik ini dikarenakan lebih dominan siswa memilih pada pernyataan negatif yaitu pernyataan yang tidak mendukung terlaksananya pembelajaran. Meskipun ada sedikit kendala dalam pelaksanaannya, namun secara keseluruhan siswa di SMPN 16 Kota Jambi telah menumbuhkembangkan sikap dalam diri mereka. Sedikit kendala tersebut juga dapat diatasi melalui kegiatan sosialisasi pembentukan karakter semangat belajar, kemudian memberikan arahan mengenai pentingnya menumbuhkan dan mengaplikasikan sikap kepedulian terhadap pelajaran IPA, serta melatih siswa agar terbiasa melakukan hal tersebut yang dimulai dari lingkungan keluarga.

\section{UCAPAN TERIMA KASIH}

Dalam penyusunan artikel ini, penulis mendapatkan banyak bantuan, bimbingan, serta arahan dari berbagai pihak. Oleh karena itu, penulis mengucapkan terima kasih kepada SMP 16 Kota Jambi beserta seluruh anggota yang telah membantu menyelesaikan tulisan ini.

\section{REFERENSI}

[1] Nurkholis. Pendidikan Dalam Upaya Memajukan Teknologi. Jurnal Kependidikan. Vol. 1 No.1. pp. 24-44.. 2013

[2] Binartika, R. Peranan Pembelajaran Sosiologi pada Lembaga Bimbingan Belajar Neutron Yogyakarta Cabang Banyumanik Semarang dalam Meningkatkan Hasil Belajar Mata Pelajaran Sosiologi di Sekolah. Solidarity: Journal Of Education, Society And Culture. Vol. 2. No.1.pp. 45-52. 2013

[3] Hadiarti, S. Kesiapan Lembaga Sekolah dalam Pelaksanaan Pendidikan Karakter Siswa di SMA Negeri 1 Batang. Solidarity: Journal of Education, Society and Culture. Vol, 2. No.1. pp. 53-59. 2013.

[4] Oktaviana, D. Dkk. Penerapan rpp berbasis multiple intelligences untuk meningkatkan aktivitas dan hasil belajar fisika siswa pada materi kalor d an perpindahan kalor kelas x mia 4 sma negeri 3 kota jambi. Jurnal edufisika,Vol. 1, No.1.pp.7-12. 2016

[5] Desstya, A., dkk.. Refleksi Pendidikan IPA Sekolah Dasar di Indonesia (Relevansi Model Pendidikan Paulo Frei re dengan Pendidikan IPA di Sekolah Dasar). Jurnal Profesi Pendidikan Dasar, Vol.4, No.1, pp.1-11. 2017

[6] Lasmita. Identifikasi Karakter Kerja Keras dalam Mata Pelajaran IPA di SMPN 3 Batanghari. Integrated Science Education Journal (ISEJ). Vol. 1, No. 1, pp. 07-15. 2020

[7] Ernawati MDW., Haryanto \& Setia. Analisis Penerapan Model Pembelajaran Kooperatif Numbered Head Together (Nht) Dan Pengaruhnya Terhadap Hasil Belajar Siswa Pada Materi Struktur Atom Di Kelas X SMKN 3 Kota Jambi.journal of the Indonesian sicienty of integrated chemistry., Vol. 9, No. 1. Pp. 45-53. 2017

[8] Astalini, Et.all. Description of scientific normality, attitudes of investigation and interested career on physics in senior high school. JIPF (Jurnal Ilmu Pendidikan Fisika).Vol. 4, No.2. Pp. 56-63. 2019.

[9] Utama Z.P, Maison, Syarkowi. Analisis Kemampuan Bernalar Siswa SMA Kota Jambi. Jurnal Penelitian Pembelajaran Fisika. Vol. 9. No.1. pp.1-5. 2018

[10] Tanti, Utu R, \& Hafiludin. Pengaruh Model Problem Based Learning Terhadap Kemampuan Pemecahan Masalah Matematis Siswa Kelas VII SMP Negeri 14 Kendari. Jurnal Penelitian Pendidikan Matematika. Vol. 8 No.2. 2020

[11] Harahap. S. Identifikasi Kreativitas Siswa Terhadap Mata Pelajaran IPA. Integrated Science Education Journal (ISEJ). Vol 1, No.1. pp. 16-22. 2020.

[12] Razak, F.M. Karakter Toleransi Siswa Pada Mata Pelajaran IPA di-SMPN 3 Muaro Jambi. Integrated Science Education Journal (ISEJ). Vol. 1, No. 2, pp. 01- 06. 2020. 
[13] Astalini, Kurniawan, D. A., \& Putri, A.D. Identifikasi Sikap Implikasi Sosial dari IPA, Ketertarikan Menambah Waktu Belajar IPA, dan Ketertarikan Berkarir dibidang IPA, Siswa SMP Se-Kabupaten Muaro Jambi. Jurnal Tarbiyah: Jurnal Ilmiah Kependidikan. Vol. 7.No. 2. pp. 93-108. 2018

[14] Tanti, Haryanto I., \& Maison. Konstruksi Dan Validasi Bahan Ajar Fisika Berbasis Masalah (Problem-Based Learning) Untuk Meningkatkan Keterampilan Generik Siswa. JoTaLP: Journal of Teaching and Learning Physics. Vol.5, No.1, pp. 28-34.2020.

[15] Tanti Dkk. Description of student science process skills on temperature and heat practicum. Jurnal penelitian dan evaluasi pendidikan. Vol.24, No.1. 2020.

[16] Naswir M, Haryanto \& Ferawati. Analisis Keterlaksanaan Model Pembelajaran Inkuiri Terbimbing Untuk Materi Sifat Koligatif Larutan Dan Pengaruhnya Terhadap Kemampuan Berpikir Kreatif Siswa Kelas XII Ipa Sma Islam Al-Falah Kota Jambi.journal of the Indonesian siccienty of integrated chemistry. Vol.9, No. 2. Pp. 43-51. 2016.

[17] Retni S. B, Ali S. Pengaruh Kartu Kwartet Animalia Dengan Model Tgt Terhadap Pemahaman Materi Taksonomi Hewan Siswa Sman 8 Kota Jambi. Jurnal BIODIK. Vol. 1 No. 1. Pp. 1-8. September 2015

[18] Sisca V, Retni S.B, Gardjito. Analisis hambatan guru biologi pada implementasi kurikulum 2013 di kelas X mia SMA negeri berakreditasi A Se-Kota Jambi. Jurnal Biodik. Vol 2, No. 2. Pp.86 - 95. 2016

[19] Harizon, Haryanto, \& Anisah. Pengaruh Penerapan Model Pembelajaran Kooperatif Tipe Make-A Match Terhadap Hasil Belajar Siswa Pada Materi Larutan Elektrolit Dan Nonelektrolit Di SMA PGRI 2 Kota Jambi. J. Indo. Soc. Integ. Chem.Vol. 8, No.2. pp. 47-56. 2016.

[20] Astuti, F., Mustofa, M. S., \& Fatimah, N. Pelaksanaan Model Pembelajaran Inovatif Problem Based Learning pada Materi Perubahan Sosial Kelas XII IPS 1 Tahun Ajaran 2015/2016 di SMA Muhammadiyah 1 Sragen. Solidarity: Journal Of Education, Society And Culture. Vol. 5. No. 1. pp. 1-9. 2016.

[21] Hanafy. M. S. Konsep Belajar dan Pembelajaran. Lentera Pendidikan. Vol.17, No.1.pp. 66-79. 2014.

[22] Kirom, A. Peran Guru dan Peserta Didik dalam Proses Pembelajaran Berbasis Multikultural. Al-Murabbi: Jurnal Pendidikan Agama Islam.Vol. 3, No.1, pp. 69-80. 2017.

[23] Sujana, A. Dasar - Dasar IPA: Konsep dan Aplikasinya. Bandung: UPI PRESS. 2014

[24] Tanti, Jamaluddin, \& Boby Syefrinando. Pengaruh Pembelajaran Berbasis Masalah Terhadap Beliefs Siswa Tentang Fisika Dan Pembelajaran Fisika. Jurnal Ilmiah Pendidikan Fisika Al-BiRuNi, Vol. 6 No.1. Pp. 23-36. April. 2017.

[25] Risma, S.S., \& Rini, S.F. Deskripsi Sikap Kesenangan dalam Belajar IPA, Ketertarikan Memperbanyak Waktu Belajar IPA, dan Ketertarikan Berkarir di Bidang IPA di MTS Syifa'u Qulub. Integrated Science Education Journal (ISEJ). Vol. 1, No. 1. Pp.39-43. 2020

[26] Sulistyaningrum, A., Prihandono, T., \& Subiki. Penerapan Model Pembelajaran Jurisprudensial Inquiry disertai Media Audio Visual pada Pembelajaran Fisika di SMA. Jurnal Pendidikan Fisika. Vol. 4. No.1, pp. 21-25. 2015

[27] Astalini \& Kurniawan, D. A. Pengembangan Instrumen Sikap Siswa Sekolah Menengah Pertama Terhadap Mata Pelajaran IPA. Jurnal Pendidikan Sains (JPS). Vol.7, No.1, pp. 1-7. 2019

[28] Widayat, W., Wiyanto, \& Hindarto, N. Pembentukan Keterampilan Berpikir Kritis dan Karakter Peduli Lingkungan Berbantuan Scaffolding. Journal of Innovative Science Education. Vol. 6.No. 1, pp. 85-95. 2017.

[29] Maison, dkk. (2018). Deskripsi Sikap Siswa Sma Negeri Pada Mata Pelajaran Fisika, EDUSAINS. Vol. 10, No. 1. 2018.

[30] Haryanto, Harizon, \& Nanda, K.R. Pengembangan Instrumen Penilaian Keterampilan Proses Dan Sikap Ilmiah Pada Materi Termokimia Kelas XI MIA SMA Negeri 10 Kota Jambi. . J. Indo. Soc. Integ. Chem.Vol. 8, No. 1. Pp. 21-53. 2015.

[31] Fujika.A., Evita A., Retni S.B. Analisis Kemampuan Berpikir Kritis Siswa Sma N 5 Kota Jambi Melalui Pembelajaran Berbasis Masalah Pada Konsep Pencemaran Lingkungan. Jurnal BIODIK. Vol.1, No. 1. Pp. 1-10. September 2015

[32] Abdurrahman, Gardjito, \& Retni.S.B. Pengembangan Lembar Kegiatan Siswa Berbasis Penemuan Terbimbing Pada Materi Struktur Dan Fungsi Jaringan Tumbuhan Kelas XI SMA. Jurnal BIODIK. Vol.1. No.1. pp. 1-8. 2015.

[33] Tanti, Dkk. Comparison of Students' Attitudes toward Natural Sciences in Rural Middle Schools in Jambi Province. TA'DIB, Vol. 23 No. 1, Juni 2020. Pp. 63-73

[34] Maison, dkk.. Deskripsi Sikap Siswa Sma Negeri Pada Mata Pelajaran Fisika. EDUSAINS. Vol.10 No. 1. 2018

[35] Astalini, Maison, Muhammad Ikhlas, Dwi Agus Kurniawan. Pengembangan Instrumen Sikap Mahasiswa Terhadap Mata Kuliah Fisika Matematika. EDUSAINS, Vol. 10, No.1. 2018.

[36] Amalla, R.P., Maison \& Darmaji. Kerjasama Dan Kekompakan Siswa Dalam Pembelajaran Fisika Di Kelas XII MIPA SMAN 3 Kota Jambi. Jurnal Edufisika Vol. 3. No. 2, pp.32-40. 2018

[37] Sanjaya, W. Penelitian pendidikan: Jenis, metode dan prosedur. Jakarta: Kencana.2013.

[38] Syahrum \& Salim. Metodologi Penelitian Kuantitatif. Bandung: Citapustaka Media. 2014. 
[39] Putra, D.S., Lumbantoruan., \& Samosir, S.C. Deskripsi sikap siswa: adopsi sikap ilmiah, ketertarikan memperbanyak waktu belajar fisika dan ketertarikan berkarir di bidang fisika. Tarbiyah: Jurnal Ilmiah Kependidikan. Vol. 8,No. 2, pp. 91-100. 2019.

[40] Mukhopadhyay, R. Scientific attitude-some psychometric considerations. IOSR Journal Of Humanities And Social Science (IOSR-JHSS) OSR-JHSS. Vol. 19,No.1, pp.98-100. 2014

[41] Astalini. Dkk. Identifikasi sikap implikasi sosial dari IPA, ketertarikan menambah waktu belajar IPA, dan ketertarikan berkarir dibidang IPA siswa SMP se-kabupaten Muaro Jambi. Jurnal Tarbiyah: Jurnal Ilmiah Kependidikan, Vol. 7.No. 2, pp. 93-108.2018

[42] Anggraini. L., \& Perdana. P. Hubungan Sikap Dan Percaya Diri Siswa Pada Mata Pelajaran IPA Di SekolahMenengah Pertama. SPEKTRA: jurnal Kajian Pendidikan Sains. Vol. 5,No.2. Pp. 188-199. 2019.

[43] Astalini. Kurniawan, D.A., \& Farida Linda, Z.N. Deskripsi sikap siswa SMA di Batanghari berdasarkan indikator normalitas ilmuan, adopsi sikap ilmiah, ketertarikan memperbanyak waktu dan ketertarikan berkarir dibidang Fisika. Vol.5, No.2, 73-80. 2018. 